\title{
Reflections on the early years of neonatology. Paul R. Swyer: the beginnings of Canadian neonatology at The Hospital for Sick Children in Toronto and insights into his early career
}

\author{
Corey Nason Reese ${ }^{1} \cdot$ Jeff Reese ${ }^{2}$
}

Received: 28 September 2017 / Accepted: 23 October 2017 / Published online: 1 February 2018

(c) Nature America, Inc., part of Springer Nature 2018

The $20^{\text {th }}$ Century witnessed significant breakthroughs in the treatment of a wide range of newborn and infant maladies as pediatricians sharpened their focus on the high mortality rate for premature and low-birth-weight infants. During the 1950 s and 60s, a handful of highly creative pediatricians from around the globe concentrated intently on understanding the unique physiology of the newborn. These physicians collaborated with their colleagues in basic science departments and adapted the latest research to modify their treatments and equipment. As a result, research laboratories and specialized nursing facilities were established to treat critically ill infants. In the midst of these developments, a young pediatrician with a keen interest in treating fragile newborns moved from his home in England to Canada.

\section{From England to Canada}

With no way of knowing it at the time, Paul Swyer would spend the rest of his life and career in Toronto, Ontario (Fig. 1). He became a neonatal pioneer with recognized expertise in positive pressure mechanical ventilation [1], nutrition research [2, 3], and regionalization and organization of neonatal care $[4,5]$. He published more than 130 manuscripts in peer-reviewed journals, authored an early textbook of Neonatology: The Intensive Care of the Newly Born. Physiological Principles and Practice [6], published in 1975 , trained more than 120 international fellows, set up

Jeff Reese

jeff.reese@vanderbilt.edu

CNR Communications, Brentwood, TN 37027, USA

2 Department of Pediatrics, Vanderbilt University Medical Center, Nashville, TN 37232, USA one of the first dedicated neonatal intensive care units in Canada, and has been honored with numerous awards [7].

Swyer began his illustrious career in the 1940 s by following in his father's footsteps and pursuing the study of medicine. However, military service in World War II interrupted his training. He selected the specialty of pediatrics, but when the war ended, a large number of military personnel were returning to resume positions they had held previously.

"I was at Great Ormond Street Hospital for Sick Children, which was the main pediatric hospital in London, and had been doing pediatric cardiothoracic medicine. I was looking around in England for an opportunity to become a Consultant Pediatrician but there was a rush of people coming out of the Services after the war (World War II), many of whom were senior to me. My Chief (Richard Erskine Bonham Carter, MD, 1910-1994)) said to me, 'Why don't you go abroad for a year?" Swyer explained [8].

He acted upon the advice of his mentor and crossed the Atlantic in 1953 for what he thought would be a year or two -to pursue pediatric cardiology training at the Hospital for Sick Children (SickKids, HSC, Toronto). Swyer brought his Belgian-born wife, Fernande and his young daughter Sandra (Michéle would be born later in Toronto). (Figs. 2 and 3) That began a busy year of balancing research interests during the day and clinical duties in a suburban pediatric practice in the evenings.

"I had a little bit of experience with newborns at Great Ormond Street and by the end of my year in cardiology in Ontario (1954), I had learned enough for the chair of Pediatrics in Toronto to offer me a part-time fellowship in newborn medicine. They didn't have enough money to pay me a full-time salary so I had to start a general practice in Pediatrics and it was difficult and stressful to manage both."

"I went to the professor's office and pleaded, 'You either find me enough money for one job so I can live, or I'm going to have to return to the UK.' That's how I got my 


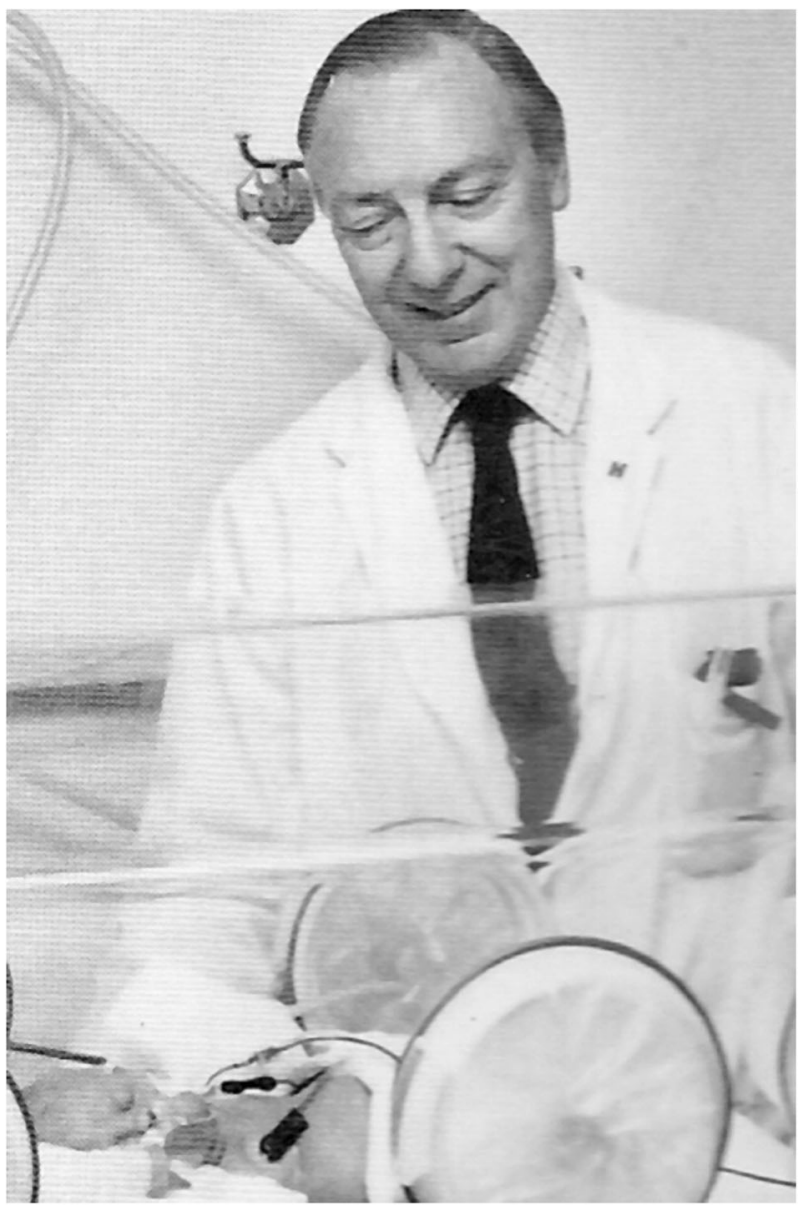

Fig. 1 Paul Swyer, MD, Professor Emeritus at the University of Toronto, served as Chief of the Division of Neonatal Medicine at The Hospital for Sick Children, Toronto, Ontario from 1964 until his retirement in 1986 full-time job as a research associate for SickKids Hospital, and I started to rev up a neonatology program. That was at the time when neonatology was just beginning. I never regretted it."

In 1955, Swyer became just the second full-time fellow in Neonatology at SickKids following Alice Goodfellow, MD, FRCPC, under then Chief of Service C.E. Snelling, MB. Swyer's research interests led him in the direction of applying assisted ventilation to infants with Respiratory Distress Syndrome (RDS). In 1960, he had begun to expand his knowledge of the essential components of neonatal survival (respiration, circulation, thermoregulation, and energy metabolism) and neonatal physiology with two sentinel investigators in those fields. He spent 3 months each with Professor Geoffrey S. Dawes (1918-1996) at the Nuffield Institute for Medical Research at the University of Oxford, England and Professor Petter Karlberg, MD (1919-2006) at the Karolinska Institute in Stockholm, Sweden.

At that time, Swyer noted that it was common for premature babies to be relatively ignored, as the prevailing sentiment was there was little that could be done for them. "There was this idea that you would take a premature newborn and place them in a rather inadequately heated incubator box with oxygen and not feed them for 3 or 4 days in case they inhaled and choked on feeds. They basically died of starvation, oxygen poisoning, and cold stress. The mortality was terrible-90 percent."

"Babies were dying of respiratory failure and we weren't treating them for respiratory failure. Additionally, these babies were born with no body energy substrate reserves. They ran out of energy within 24 hours. I thought, 'We can
Fig. 2 Paul and Fernande Swyer attend an event during their early years in Toronto

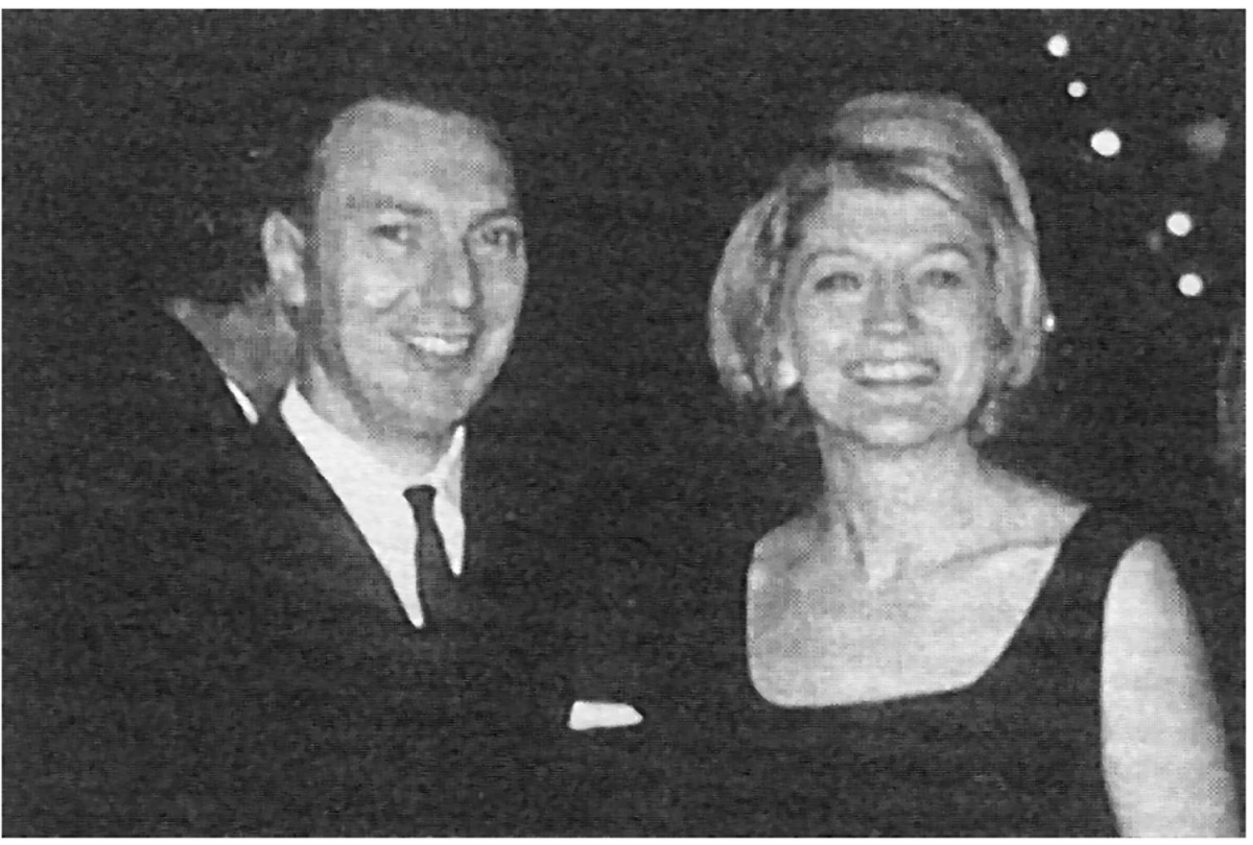


Fig. 3 Paul and Fernande Swyer attend the International Perinatal Collegium (IPC) meeting in Almalfi, Italy in 2011 with their daughters, Michéle (left) and Sandra (right)

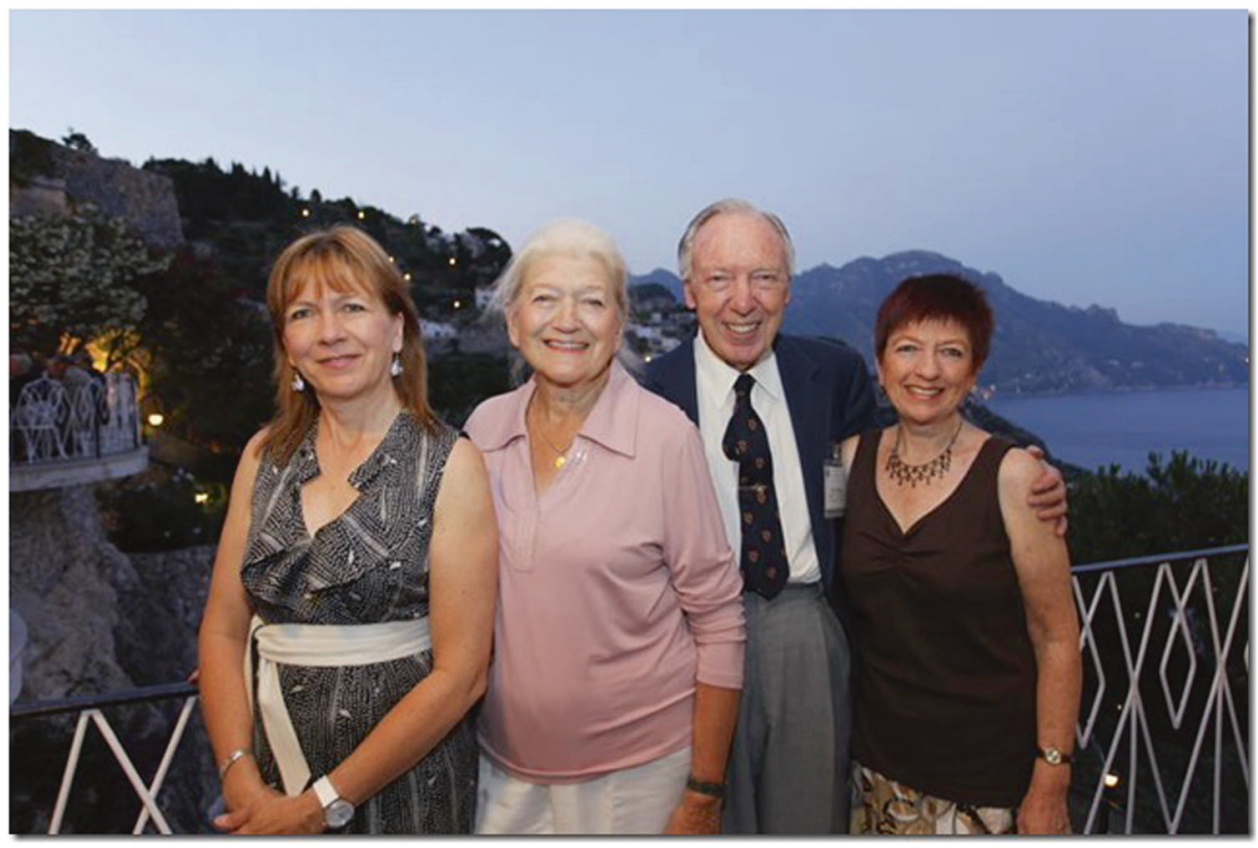

do better than this.' I set up a research lab so we could measure basic respiratory physiology parameters, including pressures, tidal volume, and oxygen uptake. Their basic respiratory physiology was unlike an adult."

Swyer further explained in his 2004 book, Babies, The Fight for Intact Survival at the Hospital for Sick Children, Toronto, Canada,

"Unfortunately, apparently until the early 1960's intubation of the airway, positive pressure recruitment of lung volume and reventilation with air/oxygen was not generally practiced, especially for low birth weight [sic] infants. As a consequence, many high risk babies failed to survive and those admitted under $1500 \mathrm{~g}$ birth weight were relatively rare (42 annually in 1961 to HSC)." [7]

\section{Mechanical ventilation research}

Swyer published two important papers in 1964 concerning his groundbreaking work at SickKids utilizing positive pressure mechanical ventilation for newborns with RDS. He had assembled an impressive team that included two of his first fellows: Maria Delivoria-Papadopoulos, MD, later professor of pediatrics, physiology and obstetrics/gynecology, Drexel University and 1997 AAP Apgar award winner [1, 9-11] (Fig. 4) and Henry Levison, MD, later Chief of Respiratory Medicine at SickKids and a colleague that

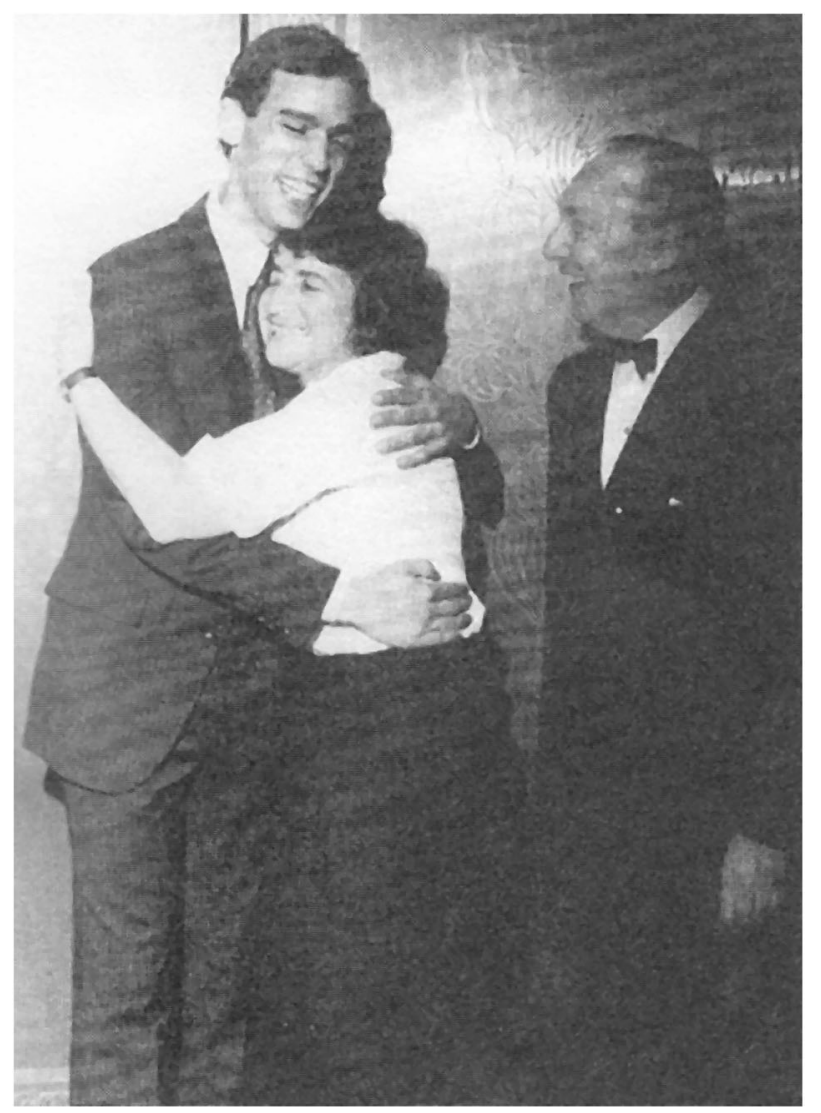

Fig. 4 Maria Delivoria-Papadopoulos, MD, former Chief of Neonatal Care, St. Christopher's Hospital for Children, Philadelphia, attends Dr. Swyer's retirement dinner in 1986 and hugs the first ventilator survivor — who she cared for as a fellow in the early $1960 \mathrm{~s}$ 
Swyer would collaborate with for more than a decade. Additionally, Blair Fearon, MD, an "inventive ENT surgeon" at SickKids performed the tracheotomies accompanying ventilation.

Delivoria-Papadopoulous and Swyer first published their results in Archives of Disease in Childhood [9], and Fearon was featured as first author later that year in a publication in the Annals of Otology Rhinology and Laryngology [12].

Their early research had focused on improving the understanding of infant respiratory mechanics and the effectiveness of supplemental oxygen in newborns [13, 14]. Prior to publishing these results, there were promising studies at SickKids [15], but they were still assembling the equipment and personnel needed to effectively resuscitate newborns. "I wasn't particularly handy but fortunately we had some good technicians. I knew what I wanted and I had a fellow, who was a respiratory physiologist, that was interested in the newborn. We obtained a whole-body plethysmograph from Dr. Kenneth Cross (FRCP, 1916-1990) in London, and we could begin to measure tidal volume with the baby in the box without any leaks in the airway and without choking. We also had to build lightweight spirometers, pressure-sensing esophageal catheters, and all sorts of things."

According to Swyer, the first ventilator used for newborns at SickKids was the positive pressure adult bird ventilator, fitted with the infant Q-Circle, designed by Sydney Segal (MD, Vancouver, 1920-1997) to reduce dead space ventilation.

The advances in what were beginning to be referred to as "neonatal" care, and the use of positive pressure ventilation, also required changes in hospitals and nurses' training. At SickKids, the first newborn intensive care unit was established in 1961-and was a single cubicle. This novel unit used research equipment to monitor infant respiration, inspired oxygen concentration, electrocardiogram, blood pressure, and core, skin and environmental temperatures.

Swyer wrote,

"The necessity to monitor and control closely the infant's vital signs, physiopathological status and environmental parameters during mechanical ventilation mandated an entirely new way of caring for the severely ill infant, designated (Neonatal) Intensive Care, analogous to the Coronary Care Intensive Care Units developing contemporaneously in adult hospitals." [7].

As Swyer and others began using assisted ventilation, they had to overcome widespread disbelief that their advances were worthwhile. This was particularly true in infants weighing under $1500 \mathrm{~g}$ at birth. Trials in Europe and South Africa experienced only limited success. Gaining consent from parents for intubation, tracheotomy, and mechanical ventilation was also a major challenge. The new treatment options were not considered ethical at the time. Community pediatricians were skeptical and argued that Swyer was saving these babies only to have them face a lifetime of handicaps. One of his colleagues referred to the room full of ventilated neonates as "Swyer's Vegetable Garden." [7].

"We started by saying we would only ventilate babies that we had failed to resuscitate by the standard method of bagging them. If they had failed to breathe within $30 \mathrm{sec}-$ onds after applying 3 to 4 minutes of resuscitation, then we would know they were dying anyway. They were what we called the 'dead' babies," Swyer said. "One of my US colleagues categorized them as 'dead, deader and deadest,' according to their blood gas and acid/base status at the initiation of ventilation. Initially, we had 3 or 4 survivorsnot from the deadest ones, but from the least 'dead' ones. The middle and worst ones all died."

Swyer also had to attend to an equipment problem when utilizing mechanical ventilation and endotracheal intubation. At that time, red rubber catheters were commonly used as endotracheal tubes, but could burn the infant's larynx if left in the airway for an extended period of time. This tubing was later found to contain a toxic tin residue from manufacturing. Due to this potential damage to infants, tracheotomies were the standard of care once the baby was stabilized on a ventilator. Swyer and Fearon creatively addressed this challenge.

Swyer wrote,

"He (Fearon) designed a ventilating bronchoscope which allowed continuous ventilation during the tracheotomy procedure and a special tube for a lower than usual tracheostomy to avoid damaging the subglottic area." Swyer continued, "It was the conventional thought that they would stop breathing when you put in the bronchoscope. If we could ventilate them at the same time, we were able to keep them ventilated while we performed the tracheostomy." [7, 16].

Swyer then followed the work of English practitioners who experienced improved results using endotracheal tubes made of Portex. He traveled to the Portex tube factory and obtained a supply of the tubes in various sizes. This led to the phasing out of tracheostomies during mechanical ventilation at SickKids.

In 1965, Swyer was appointed as Chief of the Division of Neonatology at SickKids. Respiratory distress in neonates continued to consume much of his attention, as he investigated a number of variables associated with intermittent positive pressure assisted ventilation. This included varying 
gas flow rates on arterial oxygenation, Wilson-Mikity syndrome, developing a respiratory computer for studies of the mechanics of breathing, and designing various oro-nasal masks. Over the next decade, he presented numerous symposia on ventilation and published regularly on methods and results of treating neonatal respiratory distress from continuing studies done at SickKids. [17].

\section{A growing subspecialty}

The international specialty of neonatology was coming of age in the late 1960s, with Swyer in the midst of the evolution. At the Fourth World Congress of Anaesthesiologists in London in 1968, he chaired a key symposium entitled, Artificial Ventilation in the Newborn, which was instrumental in helping to overcome the (then) current-day global skepticism of this technique [7].

The meeting also fostered informal conversations and professional contacts that led to the creation of additional key gatherings. The next year, a second symposium, Ventilation of the Newborn, was held in Paris, with Swyer contributing four papers that again discussed ventilation methods, patient monitoring, and the results of artificial ventilation at SickKids.

According to Swyer, dissatisfaction with the opportunity for discussion among the members of this new specialty, fostered by informal "rehydration exercises," were key elements that led to Swyer and S. Alvar Swensson, MD (Karolinska Children's Hospital, Stockholm, Sweden) hosting the inaugural meeting of the International Perinatal Collegium [18]. In 1971, this group of international "neonatologists" met on a remote island off the west coast of Sweden (Fig. 5). It continues to meet biennially, alternating meetings between sites in Europe and North America.

During this same time, Swyer also became a Founding Member of the Society of Critical Care Medicine, which was created in 1970 .

\section{Neonatal transport and regionalization}

The SickKids neonatal unit was gaining recognition throughout the region, but transporting sick and premature infants was problematic. Many practitioners continued to believe death was inevitable-particularly for a $1000 \mathrm{~g}$ baby - so many elected not to transfer babies. "One of the principle incidents that stimulated me to prioritize the issue of transport happened one day when I was sitting in my office and there was a knock on the door," Swyer related. "A local GP walked in with his little black doctor's bag. He opened it up and there was a $1000 \mathrm{~g}$ baby inside, wrapped in a towel whose core temperature was $28^{\circ} \mathrm{C}$ (who

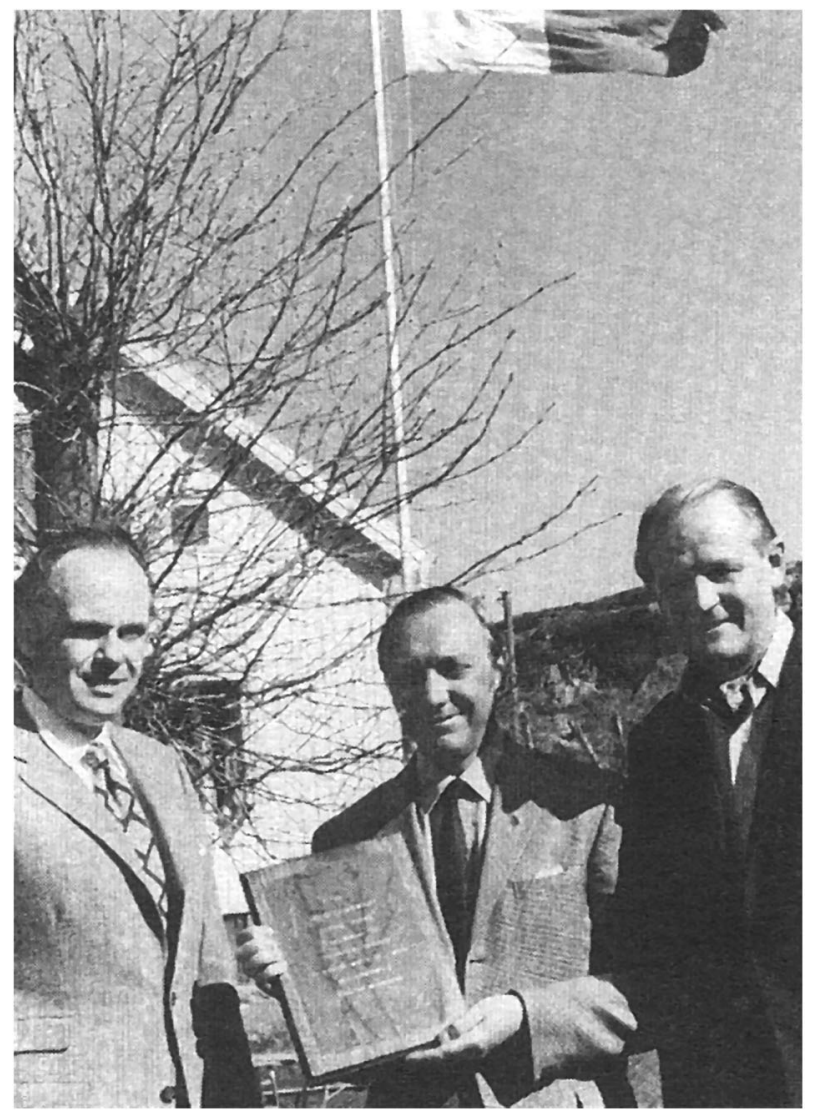

Fig. 5 Dr. Swyer helped form a new neonatal international organization in 1970Alex Lagergren (left, Swedish Roche Company), Dr. Swyer and Alvar Swensson, MD, commemorate the first meeting of the IPC at Luftsjamdet (Sailing School Stora Korno Island Sweden)

subsequently died) and he wondered if we might be able to help him. That's when we started a transport service."

Swyer and his physician and nurse colleagues, notably Graham Chance, MD, embarked on studies in the 1970s to prove the efficacy of their transport system, which included specially trained nurses and the SickKids Infant Transport Incubator, designed by John Smith, PhD, HSC Chief of Medical Engineering [19]. They compared the success of this new method of transport to the prevailing system of using an ambulance with a standard incubator box for the newborn. The clear advantage in clinical condition and in increased survival of the assisted transports [19] led the Province of Ontario to fund a system that included helicopters and fixed-wing aircraft.

He explained, "We were one of the first newborn transport systems in Canada. With Dr. Sydney Segal from Vancouver as editor, we wrote the handbook on neonatal transports for the Canadian Pediatric Society and the Americans picked it up, which made a big difference. I was actually a consultant for the American Academy of Pediatrics Newborn Committee." 
During the process of ensuring safe transportation for premature and sick infants, Swyer also began the development of an obstetric/neonatal network of clinics and hospitals. This early model provided pregnant women and their newborns with care at varying levels-according to their condition and need, irrespective of their geographical location [5].

\section{Nutritional research}

SickKids had a long history of nutritional research, beginning in the 1918 when the first SickKids nutritional research laboratory opened, and later in 1954 with the formal establishment of its Nutritional Research Institute. Significant studies were conducted in the 1920s on protein and salt metabolism, rickets, and the importance of human milk for infants [20]. As a result of this work, Fred Tisdall, MD, Theo Drake, MD, and Alan Brown, MD, created Pablum, the first ready-to-eat enriched baby cereal that provided essential vitamins, minerals, and calories [21]. Drake and Brown had previously developed Sunwheat Biscuits, which were an enriched food for children [22].

Swyer drew on the nutritional research expertise and history at SickKids and began to address his growing concern for nutrition of the newborn following ventilation.

He wrote,

"Neonatally, a food energy intake in excess of 100 $\mathrm{Kcal} / \mathrm{kg} /$ day is required for maintenance and growth. Thus, it was not surprising that these tiny infants, unfed and deprived of placental sustenance after birth, soon ran out of energy and were forced to breakdown their own body protein (muscles and internal organs) for fuel. As a result almost $90 \%$ of these pathetic miniature human beings $<1500 \mathrm{~g}$ in weight died from apnea as their wasted, starved, respiratory muscles failed." [7].

He further explained, "Ventilation failure killed them right away but malnutrition killed them within a week. I reckoned if we could feed them and give them energy reserves, we could give them a fighting chance. We had to figure out how to provide energy, so we started intravenous electrolytes and glucose, later adding amino acids and lipids and put them on oral feeding as soon as we could."

Swyer's nutrition research included milk protein, fat, and carbohydrate utilization and he focused on measurement of oxygen uptake, carbon dioxide production, and the analysis of excretions (by indirect calorimetry). A sabbatical at the University of Lausanne, Switzerland in 1974 with Professor E. Jéquier and Professor Samuel Prod'hom, MD, proved to be critical as he mastered the use of computerized indirect calorimetry.
Upon his return to Toronto, Swyer gathered a lineup of clinicians, medical engineers, fellows, and researchers who designed and built a computerized indirect calorimeter, which resulted in creation of oral and intravenous feeding regimens. Isotope technologies were then employed to measure substrate use.

Research that began during his Switzerland sabbatical continued for more than a decade. Swyer's group of researchers came from a number of European countries as well as from Canada. (Michael Clandinin, PhD; Graham Chance, MD; John M. Smith, PhD; Robert Filler, MD; Tibor Heim, MD, PhD; Paul Pencharz, MD, ChB, PhD; Pieter Sauer, MD, PhD; Stanley Zlotkin, MD, PhD; Phillipe Chessex, FRCP; Brian Reichman, MD; Guy Putet, MD, Gaston Verellen, MD; John Van Aerde, MD PhD). This group published $>20$ articles in a wide range of journals including the New England Journal of Medicine [23].

They reported their findings on energy expenditure [24], energy metabolism [25-27], and intravenous glucose [27]. In addition, Swyer published a series of manuscripts on macronutrient and fat accretion studies, and fatty acid requirements in the fetal brain [28], neonatal brain, spinal cord, and fetal and neonatal liver [28-31].

In recognition of their outstanding work, several were lauded for their collaborative discoveries and were presented with the Samuel J. Fomon Nutrition Award of the American Academy of Pediatrics (Heim 1985, Pencharz 2002, Zlotkin, 2009); the Canadian Nutritional Society's Borden Award for Nutritional Science (Pencharz 1987, Clandinin 1988, Zlotkin 1992), Khursheed Jeejeebhoy Award (Pencharz 2011), the Earl W. McHenry Award (Clandinin 2006, Zlotkin 2005, Pencharz 2004), and the Sandoz Award of the Clinical Research Society of Toronto (Pencharz 1993).

Swyer wrote,

"As a result of these researches [sic] new feeding regimens were evolved. Knowing the minimal bodily energy reserves available, a policy of early feeding for preterm infants (within hours of birth) was adopted. Intravenous glucose/amino acid/lipid mixtures were developed and used, followed as soon as possible by oral feeding with the mothers' own colostral milk and/ or protein and mineral enriched human milk or formula. This policy undoubtedly enhanced survival."

\section{International fellows}

The news that Swyer's NICU at SickKids was successfully treating preterm and sick infants through research and continual improvements in clinical care spread throughout 
Toronto and Ontario. Accordingly, the number of infants who were admitted increased. Recruiting trainees and obtaining funding became critical issues.

"As we began to be known, the place was flooded with babies from all over Ontario. I had 80 beds by 1970 . I was at my wit's end for skilled senior help because at that time the babies were admitted and nominally cared for by General Practice pediatricians. They would show up at 10 minutes before nine in the morning, discuss the baby with the House Staff and/or the fellow and say goodbye for the day. The fees would accrue to them. Our health service system wasn't working then, and as full-time staff we were all on marginal salaries."

Due to the newness of the specialty and the accompanying stress of the working environment, too few Canadian trainees were applying to fill the expanding fellowship positions. Fortunately, Swyer had maintained many of his associations and friendships from the UK and his sabbatical leaves in Stockholm, Oxford, and in Switzerland.

He filled the void by recruiting fellows from Europe, the UK, British Commonwealth countries and the US. A steady stream of international fellowship trainees-more than 120 from 1961 to 1986, from 24 countries-trained under Swyer and his colleagues at SickKids. The funding came from the Canadian Medical Research Council, the SickKids Research Institute, and certain unrestricted funds for nutritional studies that were provided by the Mead Johnson Company.

\section{Reflections}

In 1986, Swyer retired from clinical practice at the age of 65 -in accordance with Canadian regulations. He continued to publish his research findings and throughout his retirement remained active on hospital committees. In 2004, he published his personal view of the development of neonatal/ perinatal medicine at SickKids. "I had 25 years of intensive clinical work, and had to retire at 65 , but it (the NICU) was very wearing. You have a finite time for effective neonatal clinical practice. I then stayed on the research advisory committee at the hospital."

Throughout his lengthy career, Swyer's international connections were apparent as the NICU at SickKids welcomed a long list of visitors from around the world. From 1964 to 1986, Swyer maintained a Visitors' Book that recorded more than 1300 visitors (Fig. 6). The first visitor listed was Professor Robert Debré, the brother of President of France in 1964. Dr. Sun Quingyi of Shanghai Children's Hospital was the final entry that completed the book.

Swyer wrote:

"In between, there is a roll call of Paediatrician/ Neonatologists such as Clement Smith; Stan James; Geoffrey Dawes; Osmund Reynolds; Peter Tizard; Virginia Apgar; David Baum, President Royal College of Paediatrics of the U.K.; V. Grigorieva, President of the Medical Worker's Union, Moscow, U.S.S.R.; Dr. Bette Stephenson, Chair Canadian Medical Association Board of Directors and subsequently Ontario Minister of Health. There were also some notable lay visitors, King Baudouin and Queen Fabiola of Belgium; Her Highness the Begum Salimah Aga Khan; Mme Lin Jai Li, wife of the President of the Republic of China, escorted by Mrs.
Fig. 6 King Baudouin and Queen Fabiola of Belgium visit Dr. Swyer's unit at the Hospital for Sick Children, Toronto

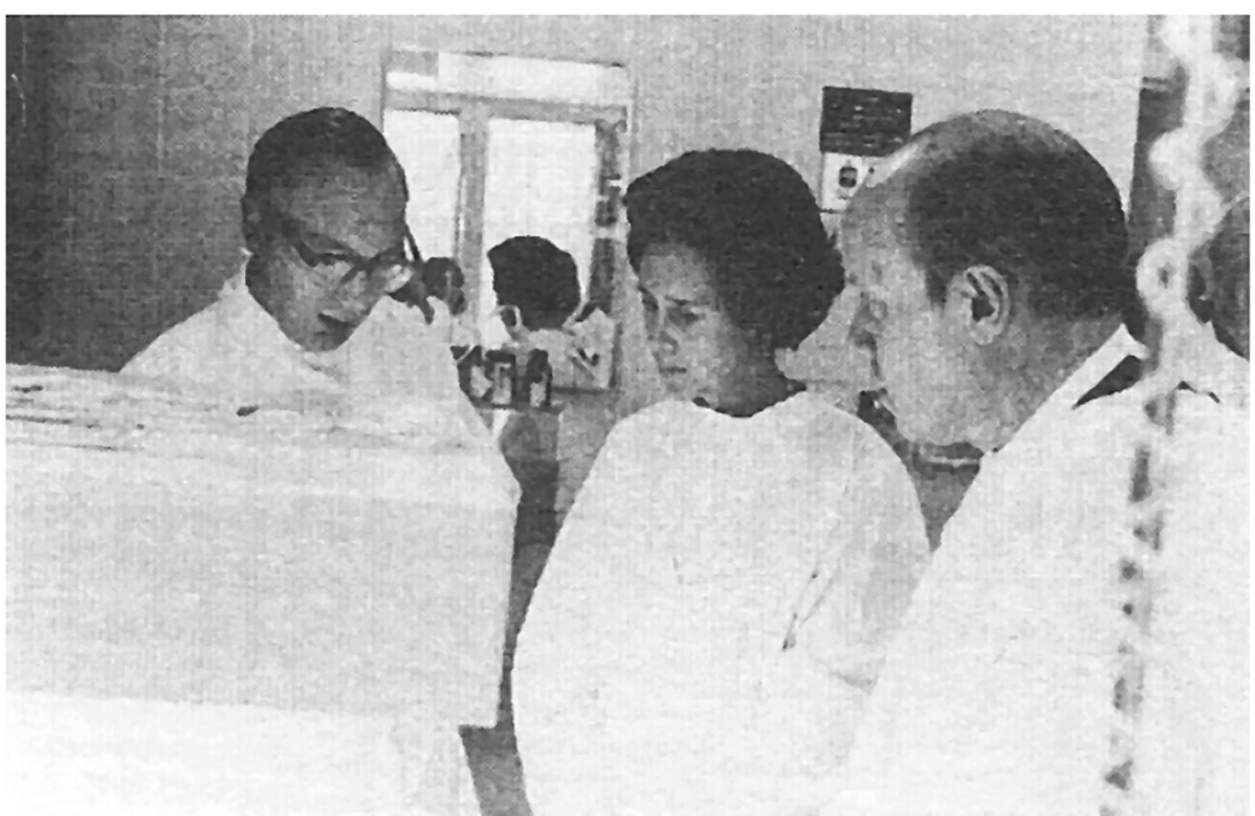


Fig. 7 Mrs. Fernande and Dr. Paul Swyer on a ferry in Amalfi, Italy 2011

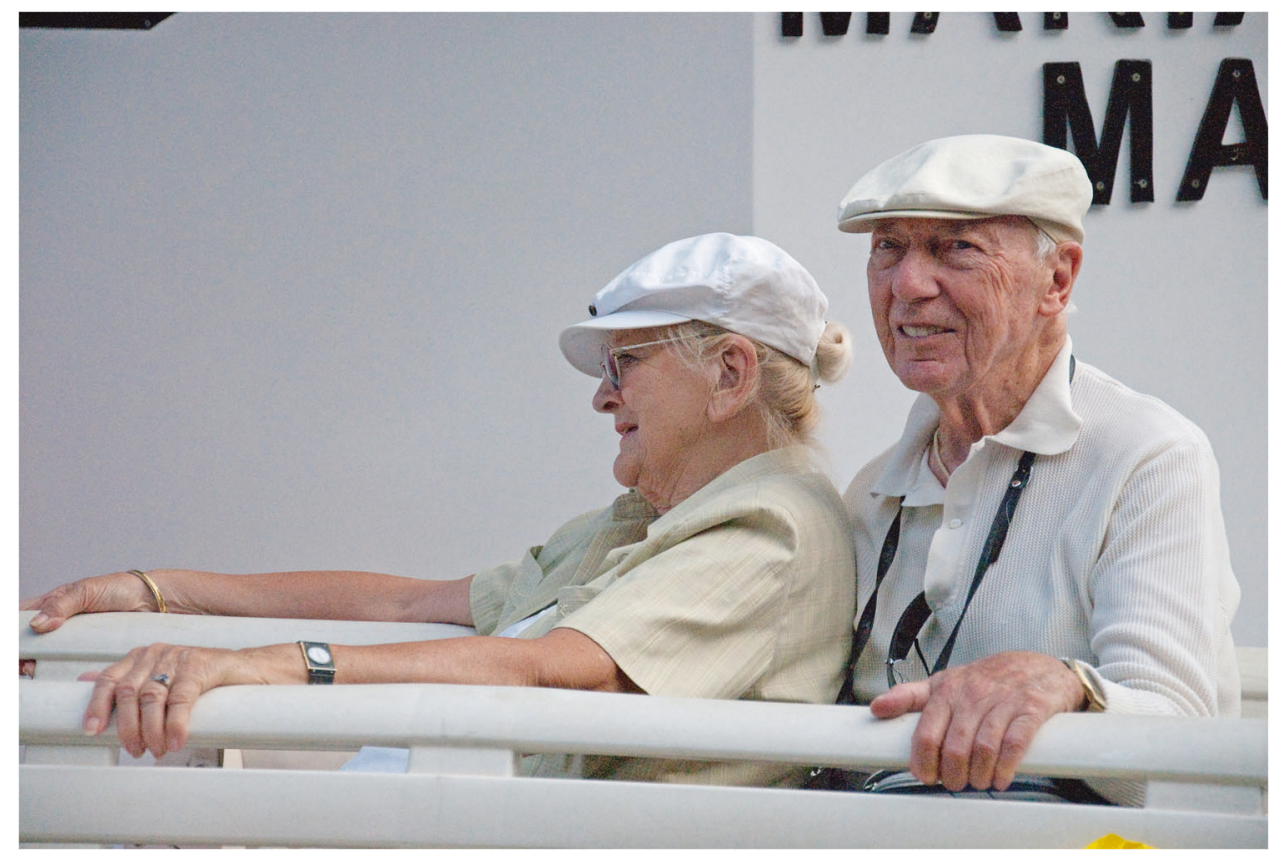

Shelley Peterson, wife of the Premier of Ontario; Dennis Timbrell, Minister of Health, Ontario and many other notables."

Reflecting on the early days of his career, he said, "The babies were dying of respiratory failure and starvation. The difference is that nowadays they die of more intractable infection or prematurity or complications, whereas then they were dying of relatively simple and treatable problems."

"Things are changing-initially, we worked to get the basics in place. Now, the details are being filled in. What we did was try to clarify the neonatal pathophysiology-what was going wrong with breathing, for example and try to remedy it. Now it is getting very sophisticated and specific. It is all very important, but in the beginning there just was not time for that. We had greater urgency-the babies were dying. The fact of the matter was-the mortality for the $1000 \mathrm{~g}$ baby was $90 \%$ when I started. It was $10 \%$ when I retired" (Fig. 7).

\section{Notables who trained under Dr. Swyer}

Olivier Claris, MD, PhD, Professor of Pediatrics \& Vice Dean, Université, Claude Bernard, Faculté de Medecine Lyon-Est, Lyon, France.

Christian Debauche, MD, Professor, Université SaintLuc, Université Catholique de Louvain, Brussels, Belgium.

Maria Delivoria-Papadopoulos, MD, Greece, Professor of Pediatrics and Physiology, Drexel University College of Medicine, Philadelphia, PS, USA.
Jack Feng, Guanzchou Province, Republic of China, former Vice President and Chief of Neonatology, Jinan University, China.

Henry Levison, MD, former Chief of Respiratory Medicine, HSC Toronto.

Guy Putet, MD, Professor of Pediatrics, Université Claude Bernard, Head of Neonatal Unit, Hôpital de la Croix-Rousse, Lyon, France.

R. Neil Roy, FRACP, former Director of Neonatal Services, Royal Women's Hospital, Melbourne, Australia.

Bernard L. Salle, MD, Professor, Chief of Neonatology, Dean of Medicine, Faculté de Medecine Lyon-Est, Université Claude Bernard, Lyon, France.

Pieter Sauer, MD, Professor of Pediatrics and Chairman of the Department of Pediatrics/Beatrix Children's Hospital, University of Groningen, the Netherlands.

John Van Aerde, MD, PhD, FRCPC, Belgium, Professor and Former Regional Director of Neonatology, University of Alberta Hospitals, Edmonton, Canada.

Gaston Verellen, MD, Professor Emeritus, Université Catholique de Louvain, Former Professor and Chief of Neonatal Division, Pediatrician to the Belgian Royal Household, Brussels, Belgium.

Paul Vert, MD, Professor Emeritus, Former Chief of Neonatal Service, Maternité Régionale A. Pinard, Nancy, France.

Hillary Whyte, MB, FRCPC, Medical Director, Neonatal Intensive Care Unit, HSC, Professor of Paediatrics, University of Toronto, Canada. 


\section{Swyer's awards}

Oxford and Cambridge Universities Entrance Scholarshipfirst place, Middlesex Hospital Medical School, University of London, 1940.

Fellowship of the Royal College of Physicians of London, elected 1974.

Honorary Doctorate in Medicine, University of Lausanne, Switzerland, 1984.

Doctorate of Medicine, University of Cambridge, 1984.

Distinguished Service Award, Section of NeonatalPerinatal Medicine, Canadian Paediatric Society, 1995.

Competing interests The authors declare that they have no competing financial interests.

\section{References}

1. Philip AGS. Historical Perspectives: forty years of mechanical ventilation...then and now. Neoreviews. 2003;4:e335-9.

2. Swyer PR. The future of nutrition for the low birth-weight infant. Acta Paediatr. 1995;84:210-2.

3. Swyer PR. New perspectives in neonatal nutrition. Biol Neonate. 1987;52:4-16.

4. Swyer PR. The regional organisation of special care for the neonate. Pediatr Clin North Am. 1970;17:761-76.

5. Swyer PR, Goodwin JW. Regional Services in Reproductive Medicine. The Joint Committee of the Society of Obstetricians and Gynaecologists of Canada and Canadian Paeditric Society, Ottawa 1973.

6. Swyer PR. The intensive care of the newly born. Physiol Princ Pract Monogr Paediatr. 1975;0:1-208.

7. Swyer PR. Babies. The Fight for Intact Survival at the Hospital for Sick Children, Toronto. 1875-2000. A Personal View.; 2004.

8. Reese CN. Interview with Paul Swyer, MD, 2011.

9. Delivoria-Papadopoulos M, Swyer PR. Assisted ventilation in terminal hyaline membrane disease. Arch Dis Child. 1964; 39:481-4.

10. Levison H, Delivoria-Papadopoulos M, Swyer PR. Oxygen consumption in newly born infants with the respiratory distress syndrome. Biol Neonat. 1964;7:255-69.

11. Delivoria-Papadopoulos M, Levison H, Swyer PR. Intermittent positive pressure respiration as a treatment in severe respiratory distress syndrome. Arch Dis Child. 1965;40:474-9.

12. Fearon B, Smith C, Delivoria-Papadopoulos M, Levison H, Swyer PR. The idiopathic respiratory distress syndrome in the newborn; management by tracheotomy and intermittent positive pressure respiration. Ann Otol Rhinol Laryngol. 1964;73:1082-94.

13. Swyer PR. The physiological basis for supplemental oxygen in the newborn. Can Med Assoc J. 1958;78:236-40.

14. Hanley WB, Braudo M, Swyer PR. Neonatal respiratory distress: experience at the Hospital for Sick Children, Toronto, L960-1961. Can Med Assoc J. 1963;89:375-81.
15. Swyer PR, Reiman RC, Wright JJ. Ventilation and ventilatory mechanics in the newborn: methods and results in 15 resting infants. J Pediatr. 1960;56:612-22.

16. Fearon B, Smith C, Delivoria-Papadopoulos M, Levison H, Swyer PR. The idiopathic respiratory distress syndrome in the newborn: management by tracheotomy and intermittent positive pressure respiration. Trans Annu Meet Am Bronchoesophagol Assoc. 1964;44:90-105.

17. Swyer PR. Results of artificial ventilation. Experience at the Hospital for Sick Children, Toronto. Biol Neonate. 1970; $16: 148-54$.

18. Oh W. A brief history of international perinatal collegium. Acta Paediatr. 2017;106:5-32.

19. Chance GW, O'Brien MJ, Swyer PR. Transportation of sick neonates, 1972: an unsatisfactory aspect of medical care. Can Med Assoc J. 1973;109:847-51.

20. About SickKids - Our History. http://www.sickkids.ca/ AboutSickKids/History-and-Milestones/Our-History/index.html. Accessed September 1, 2017

21. McLaughlin D. 'Open Wide' for better baby nutrition. About the Faculty of Medicine. 2017. http://medicine.utoronto.ca/about-fa culty-medicine/'open-wide'-better-baby-nutrition/.

22. McLeod S. Canadian Ingenuity: Sunwheat biscuits and Pablum to the rescue for sick kids. Kingston Whig-Standard, October 1, 2013. http://www.thewhig.com/2013/10/01/sunwheat-biscuits-a nd-pablum-to-the-rescue-for-sick-kids. Accessed September 3, 2017.

23. Reichman B, Chessex P, Putet G, Verellen G, Smith JM, Heim T, et al. Diet, fat accretion, and growth in premature infants. $\mathrm{N}$ Engl $\mathrm{J}$ Med. 1981;305:1495-1500.

24. Jones PJ, Winthrop AL, Schoeller DA, Swyer PR, Smith J, Filler RM, Heim T. Validation of doubly labeled water for assessing energy expenditure in infants. Pediatr Res. 1987;21:242-6.

25. Chessex P, Reichman BL, Verellen GJ, Putet G, Smith JM, Heim $\mathrm{T}$, Swyer PR. Influence of postnatal age, energy intake, and weight gain on energy metabolism in the very low-birth-weight infant. J Pediatr. 1981;99:761-6.

26. Swyer PR. Assumptions used in measurements of energy metabolism. J Nutr. 1991;121:1891-6.

27. Van Aerde JE, Sauer PJ, Pencharz PB, Smith JM, Swyer PR. Effect of replacing glucose with lipid on the energy metabolism of newborn infants. Clin Sci. 1989;76:581-8.

28. Clandinin MT, Chappell JE, Leong S, Heim T, Swyer PR, Chance GW. Intrauterin fatty acid accretion rates in human brain: implications for fatty acid requirements. Early Hum Dev. 1980;4:121-9.

29. Clandinin MT, Chappell JE, Heim T, Swyer PR, Chance GW. Extrauterine fatty acid accretion in infant brain: implications for fatty acid requirements. Early Hum Dev. 1980;4:131-8.

30. Clandinin MT, Chappell JE, Heim T, Swyer PR, Chance GW. Fatty acid accretion in the development of human spinal cord. Early Hum Dev. 1981;5:1-6.

31. Clandinin MT, Chappell JE, Heim T, Swyer PR, Chance GW. Fatty acid accretion in fetal and neonatal liver: implications for fatty acid requirements. Early Hum Dev. 1981;5:7-14. 